OPEN ACCESS

Edited by:

Elnara Shafiyeva,

Baku State University, Azerbaijan

Reviewed by:

Ling Wang,

King's College London,

United Kingdom

Si-Tong Chen,

Victoria University, Australia

*Correspondence:

Shalini Quadros

shalini.quadros@manipal.edu

Mohammed A. Mamun

mamunphi46@gmail.com

tThese authors have contributed equally to this work

\#ORCID:

Shalini Quadros

orcid.org/0000-0001-6250-1730

Shalini Garg

orcid.org/0000-0002-2607-488X

Rupesh Ranjan

orcid.org/0000-0002-3792-9521

Guruprasad Vijayasarathi orcid.org/0000-0002-7144-9652

Mohammed A. Mamun orcid.org/0000-0002-1728-8966

Specialty section:

This article was submitted to Public Mental Health a section of the journal

Frontiers in Psychiatry

Received: 11 May 2021

Accepted: 05 July 2021

Published: 07 September 2021

Citation:

Quadros S, Garg S, Ranjan R, Vijayasarathi $G$ and Mamun MA (2021)

Fear of COVID 19 Infection Across Different Cohorts: A Scoping Review.

Front. Psychiatry 12:708430.

doi: 10.3389/fpsyt.2021.708430

\section{Fear of COVID 19 Infection Across Different Cohorts: A Scoping Review}

\author{
Shalini Quadros ${ }^{1 * \neq \neq}$, Shalini Garg ${ }^{2 \neq \neq}$, Rupesh Ranjan ${ }^{3 \neq}$, Guruprasad Vijayasarathi ${ }^{1 \neq}$ and \\ Mohammed A. Mamun ${ }^{4,5 * t}$
}

\begin{abstract}
'Department of Occupational Therapy, Manipal College of Health Professions, Manipal Academy of Higher Education, Manipal, India, ${ }^{2}$ Achutha Menon Centre for Health Science Studies, Sree Chitra Tirunal Institute of Medical Sciences and Technology, Thiruvananthapuram, India, ${ }^{3}$ National Homoeopathy Research Institute in Mental Health, Kerala Central Council for Research in Homeopathy, Ministry of Ayurveda, Yoga and Naturopathy, Unani, Siddha and Homeopathy Government of India, Kottayam, India, ${ }^{4}$ CHINTA Research Bangladesh, Dhaka, Bangladesh, ${ }^{5}$ Department of Public Health and Informatics, Jahangirnagar University, Dhaka, Bangladesh
\end{abstract}

Background: Psychological stressors like panic, fear, phobia, etc., are being substantially reported during the COVID-19 outbreak. In the prior outbreaks, fear of being infected was reported as the prominent suicide stressor. Therefore, fear of infection has become a concern in the context of the COVID-19 pandemic because it worsens emotion, cognition, and behavioral responses. Understanding the extent of fear of COVID-19 infection in various cohorts would aid in gauging the mental health services, which was a remedy in the present review.

Methods: Adhering to Arksey and O'Malley's framework for conducting a scoping review, a systematic search was performed in the month of September 2020 in several databases, including Scopus, PubMed, Web of Science, etc. Considering the inclusion criteria, a total of 14 articles were included in the present review.

Results: All of the included studies were conducted via online platforms, whereas all but one of the studies were cross-sectional in nature (including a mixed-method study, and a comparative study). Most of the studies were conducted among the general population ( $n=12)$, within March and May $2020(n=9)$, from Asian countries $(n=7)$, and considered a self-developed item for fear of COVID-19 assessment $(n=8$; whereas the Fear of COVID-19 Scale was used in 6-studies). The prevalence of fear of COVID-19 was reported to be $18.1-45.2 \%$, although no cutoff point or criteria was mentioned for such a prevalence estimation of the Fear of COVID-19 Scale. However, females, younger adults, urban residents, divorcees, healthcare workers, those in quarantine settings, those in suspicion of being infected, and those with mental health problems, etc., were found to be at an increased risk of COVID-19 fear.

Conclusions: Being one of the first reviews in this context, the findings are anticipated to be helpful to predict the possible solutions for reducing fear of COVID-19 and facilitate further studies on strategies of how to alleviate such a stressful situation.

Keywords: COVID-19 and psychological impact, fear of COVID-19, Covid-19 panic, fear of infection, mental health, scoping review, COVID-19 fear, prevalence and risk factors 


\section{INTRODUCTION}

COVID-19 is a disease which is infectious in nature and caused by the newly introduced virus named SARS-CoV-2. Individuals infected with this virus generally present the symptoms of fever, body ache, cough, nasal congestion, loss of taste and smell in milder cases, and chest pain and breathing difficulties in severe cases. Because of its rapid transmission globally, the WHO declared it a pandemic in early 2020. However, more than 152 million people worldwide are infected with the virus, whereas more than 3.19 million deaths are recorded as of 5 May 2021.

The COVID-19 pandemic has not only resulted in physical conditions, social, psychological, and economic consequences are also being observed globally; whereas the combined role of the alteration of normal life leads people to suffer from a higher degree of mental health problems, including fear of infection, uncertainty, stress, anxiety disorders, sleep problems, mood disorders, suicidality etc. (1-3). Public health interventions have increased the feelings of discomfort and economic loss, which mediates the mental instabilities more harshly (4). Additionally, changes in daily lives and restriction of movement such as working from home, schooling, restricted play for children, and restricted contact with friends and family have led people to suffer from higher stress and anxiety levels $(4,5)$. As per the Centre for Disease Control and Prevention (5), fear and stress related to the COVID-19 have led to symptomatology, including change in sleep and eating patterns, worsening of premorbid psychiatric conditions, and increased use of substances (e.g., alcohol, tobacco, drugs), which are frequently alleged for mental health burdens (6).

During the COVID-19 pandemic, suicide mortality rate increment is being observed as consistent with the prior pandemics (7). However, four major types of suicide stressors have been identified in the prior pandemics, whereas fear of being infected was regarded as the prominent suicide factor followed by social isolation, disruption of normal life, and burden of longterm illness $(8,9)$. In the context of the COVID-19 pandemic, fear of COVID-19 infection is also reported as the main suicide mediating factor $(1,7,10,11)$. Studies have identified various domains of fear related to the fear of COVID-19 infection, such as fear of oneself or their family members getting infected, fear of having economic losses and being unemployed, or fear of avoidance behaviors toward gaining knowledge about the pandemic or fear of making decisions on showing or not showing actions like whether to visit parents or not, whether to look for information on death rates or not, etc. $(12,13)$. The deaths caused due to the pandemic have been enormous, inflicting a sense of fear among people. However, people worrying about being infected with the virus is being regarded as the fear of COVID19 despite the diversity of fears related to the pandemic $(6,14)$, which are also investigated in this review.

Fear is defined as "a basic, intense emotion aroused by the detection of imminent threat, involving an immediate alarm reaction that mobilizes the organism by triggering a set of physiological changes" (15). During the current pandemic, the fear was about either being infected or infecting others (14, 16). Understanding fear is an important part of individual and community well-being as it influences how an individual participates in daily occupations. Occupational participation is the ability of an individual to participate in occupations of their choice, and is the satisfaction given within the boundaries of the culture (17). The fear might also affect how people react to control guidelines required as preventive measures that aid in the overall outcome of the disease transmission in the community (18). The fear of COVID-19 infection has led many individuals to abort their participation in social activity (19), which even leads to suicidal attempts in extreme cases $(7,10,11)$. Due to the guidelines enforced to control the pandemic, people are deprived of participation in various occupations such as participating in social gatherings, traveling, and so on, which means an imposed lack of opportunities to participate in various occupations for reasons not under the control of individuals, and this occupational deprivation leads to ill-health (20).

As the pandemic gradually extended across the globe, the effects have been experienced in the population at large and certain groups within. While stress-related to fear of being infected, loss of lives and livelihoods are affecting the entire population, certain groups like older adults, healthcare workers, caregivers, migrants, women and children exposed to abuse, people with pre-existing mental health conditions, and people with disabilities, who are already vulnerable need to be given special mental health attention (21-23). As fear may help in explaining several of these consequences, it is important to understand what creates this fear and what the predictors are (3).

Longstanding fear may stimulate the behavioral immune system, which usually leads to aversive emotions, cognition, and behavioral responses (24). Though these aversive behaviors initially help in staying away from illnesses (25), prolonged exposure to fear may lead to emotional and distress-related disorders (26). Understanding the extent of this fear of infection in various populations would aid in gauging the extent of community mental health services needed for different population groups to meet the needs of the people who experience the psychological responses that have occurred due to the fear of infection. In addition, meaningful occupations are necessary for experiencing well-being (27), and hence an understanding of the kind of occupations that are affected due to the fear of COVID-19 may help in thinking of innovative ways through which occupational participation can be facilitated in individuals.

Scoping reviews allow us to map evidence and synthesize knowledge on a topic following a systematic approach and identify main concepts, theories, and knowledge gaps (28). This review can help map the extent of the evidence on a given topic and identify gaps in the literature to help determine the direction of future research $(28,29)$. In this scoping review, therefore, we attempt to map evidence on the fear of COVID-19 across various groups of the population to seek factors that affect fear and the consequences of fear related to the COVID-19 pandemic in the short-term and long-term health of individuals. The present review is anticipated to entail the extent of this problem in different populations, identify various groups at increased risk, and identify gaps in the literature to focus our future research on this global crisis. 


\section{METHODS}

The initial framework was proposed for scoping reviews by Arksey and O'Malley (30), later on, it was extended by other researchers (28). However, as it is widely used, Arksey and O'Malley's framework was used in this scoping review. Accordingly, the methodology is described in the following stages:

- Stage 1. Identifying the research question,

- Stage 2. Searching for relevant studies,

- Stage 3. Selection of studies,

- Stage 4. Charting of data,

- Stage 5. Collating, summarizing, and reporting the results

\section{Stage 1: Identifying the Research Question}

All five reviewers contributed to refining the research question through frequent discussions and pilot searching. Based on the discussion, the reviewers came up with the following research question: "What is the available literature on the effects of fear of COVID-19 across different populations?" Therefore, the objectives of the current scoping review were decided as follows: (i) to review the literature available on the existence of fear of COVID-19 in children, adolescents, adults, and older adults, (ii) to map the literature available on the factors related to the fear of COVID-19 that influence occupational participation of children, adolescents, adults, and older adults (if there is available literature across these cohorts).

\section{Stage 2: Searching for Relevant Studies}

Having specific criteria for searching the relevant articles is a requirement to answer the question framed for any scoping review (30). Hence, following the inclusion criteria were decided on for the scoping review by all the reviewers.

The databases Scopus, PubMed/MEDLINE, ProQuest, Web of Science, Journal Citation Reports, CINAHL Plus etc., were accessed for retrieving relevant articles. The search strategy included 4 types of keywords: (i) outcome of interest (fear OR scare OR terror OR dread); AND (ii) exposure (COVID-19 OR lockdown OR quarantine OR isolation); AND (iii) cohort (children OR kid OR adolescent OR teenager OR youth OR adults OR elderly OR geriatric); AND (iv) Occupation (activities OR activities of daily living OR self-care OR work OR housework OR leisure OR sleep OR social participation OR education). Searches were performed in combination with the keywords in the month of September 2020. However, the inclusion and exclusion criteria for including studies in the present review are presented in Table 1.

\section{Stage 3: Selection of Studies}

SG and RR reviewed titles and abstracts to identify the first set of articles relevant to our research question. Any kind of disagreement was resolved after consulting with GV. If any disagreement still existed, then the article titles were still included in the initial list. The reviewers GV and SQ blindly reviewed the abstracts included in the first list, and in case of any disagreement, reviewers SG and MM were approached for finalizing the decision. The full text of all the articles included in the first list was searched for. All possible ethical ways (such as contacting the author, requesting the library) were tried to obtain the full text of any article that was not available freely on search. The final version of full-text articles was blindly reviewed by SG, $\mathrm{RR}, \mathrm{GV}$, and SQ independently. If the reviewers came up with any discrepancies, the matter was discussed and finalized with consultation from MM.

Figure 1 illustrates the search done while conducting this scoping review that has adhered to the PRISMA-ScR (Preferred Reporting Items for Systematic Reviews and Meta-Analysis extension for Scoping Reviews) guidelines (29).

\section{Stage 4: Charting of Data}

Data extraction criteria of the present scoping review were determined, and a self-designed data extraction form was designed by consultation of the reviewers before aiding the process. The included articles were reviewed in full-text and summarized under the headings as mentioned in Table 2. The reviewers independently summarized the findings and crosschecked with each other, and the final outline is presented in the Table. In respect to providing answers to the study question, data extraction from the included studies were as follows: a bibliography of the study (author's name and publication date), data collection time, study design, sample size, country of the study conducted, specific group and mean age, participants being COVID-19 infected or suspected, and outcome(s).

\section{RESULTS}

\section{Description of the Included Studies General Description of the Studies}

A total of 14 studies were included in this review, where eleven studies were reported to have been conducted between March and May 2020. Out of 14 studies included herein, all were conducted via online platforms. Thirteen studies were cross-sectional in nature (including one mixed-method and one comparative study), whereas one was a longitudinal study. The sample size of the studies varied from 121 to 15037 . Most of the studies were conducted among the general adult population, a study was conducted among children and adolescents (mean age $=15.4$ years), and another study was conducted among college students (mean age $=19.6$ years). In respect to the geographical location, most of the included studies $(n=7)$ were conducted in Asian countries [i.e., Bangladesh (38), China (40); India $(18,41)$; Lebanon (37); Philippines (19); and Turkey (33)], where no studies belonged to African and Australian continents.

\section{Measures Used in the Studies}

In most of the studies, fear of COVID-19 was assessed using a self-developed item $(n=7)$, whereas the Fear of COVID-19 Scale was used in a total of 6-studies. Note, the Fear of COVID-19 Scale assesses the fear that exists specifically related to the COVID-19 infection (14). Three studies used a validated version of the Fear of COVID-19 Scale in the languages of Brazilian (32), Turkish (33), and Spanish (Cuban) (35) and the original scale was used in three studies. Self-developed items were used to assess different kinds of variables like socio-demographic, health problems, 
TABLE 1 | Inclusion/exclusion criteria for including studies in the present review.

\begin{tabular}{|c|c|c|}
\hline & Inclusion criteria & Exclusion criteria \\
\hline Population & Studies on participants with or without being positive for COVID-19 & $\begin{array}{l}\text { Studies conducted on healthcare workers and individuals with specific } \\
\text { illnesses }\end{array}$ \\
\hline Intervention & Literature focusing on fear of COVID-19 & Studies conducted on general mental status \\
\hline Comparison & $\begin{array}{l}\text { Studies comparing the extent of fear across various cohorts such as } \\
\text { children, adolescents, adults, and older adults }\end{array}$ & Studies comparing fear between individuals with and without illnesses \\
\hline Outcome & Fear of COVID-19 & Not related to fear of COVID-19 \\
\hline Others & $\begin{array}{l}\text { Studies published in the English language from December } 2019 \text { to } \\
\text { August } 2020 \text { and studies with full-text being available by journal or } \\
\text { pre-print server }\end{array}$ & $\begin{array}{l}\text { Publications of letters to editors, correspondence, point of views, } \\
\text { ideas, opinions, studies exclusively done on healthcare workers, } \\
\text { studies on development and validation of the fear scales }\end{array}$ \\
\hline
\end{tabular}

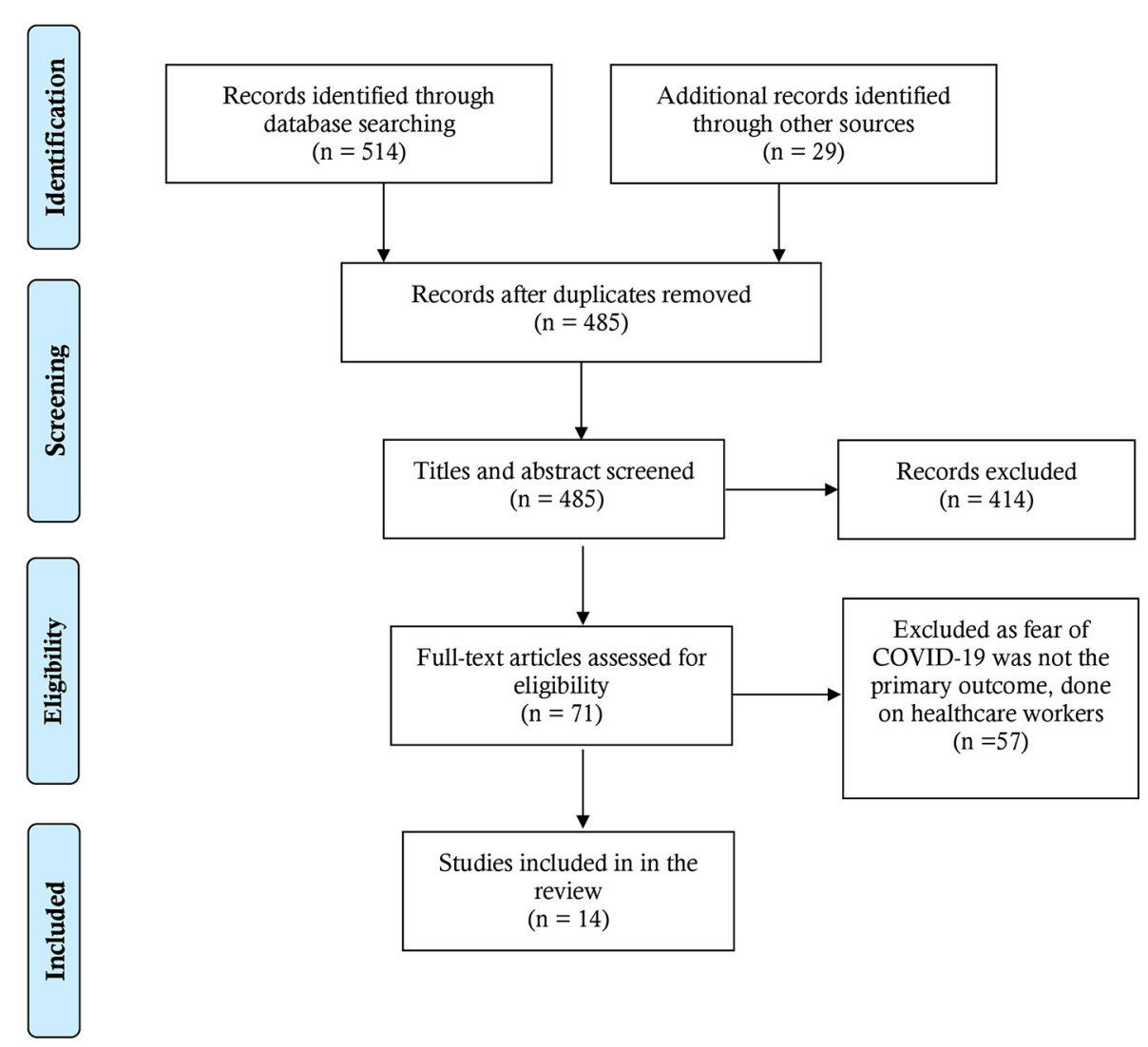

FIGURE 1 | PRISMA flow-chart of this scoping review (31).

COVID-19 related issues, etc.; whereas psychological problems (e.g., depression, anxiety, stress, intolerance of uncertainty etc.) were assessed using respective psychometric tools.

\section{Prevalence of Fear of COVID-19}

The prevalence of COVID-19 fear assessing by the Fear of COVID-19 Scale was reported in two studies $(18,42)$. Doshi et al. (18), in the Indian study, estimated that $45.2 \%$ of subjects feared about COVID-19, although no cutoff point was mentioned for such a prevalence estimation. Similarly, an $18.1 \%$ prevalence of strong fear associated with COVID-19 was also reported by Šljivo et al. (42) without any clarification about the used cutoff score.
In addition, a 5-point Likert scale-based ten-item was used to determine higher fear of COVID-19 in another study (44.8\%), although the cutoff point was not reported (37).

\section{Factors Associated With Fear of COVID-19}

Gender was reported as the most consistent predictor, with more women experiencing moderate to high fear levels of COVID$19(18,32,33,35,36,42)$. Age was also significantly associated with fear of COVID-19 as per a few studies, and it was generally found that older people were less scared of the disease (32, 42). Another interesting predictor of COVID-19 fear was an occupational risk, that is, being engaged in high COVID-19 risk 
TABLE 2 | Descriptions of the included studies in the present review.

\begin{tabular}{|c|c|c|c|c|c|c|c|c|}
\hline References & $\begin{array}{l}\text { Data } \\
\text { collection } \\
\text { time }\end{array}$ & $\begin{array}{l}\text { Study } \\
\text { design }\end{array}$ & $\begin{array}{l}\text { Sample } \\
\text { size }\end{array}$ & Country & $\begin{array}{l}\text { Specific group and mean } \\
\text { age }\end{array}$ & $\begin{array}{l}\text { Being COVID-19 infected } \\
\text { or suspected }\end{array}$ & Assessment tool & Outcome(s) \\
\hline Andrade et al. (32) & $\begin{array}{l}\text { May } 12 \text { to } 24, \\
2020\end{array}$ & $\begin{array}{l}\text { Cross- } \\
\text { sectional }\end{array}$ & 1,743 & Brazil & $\begin{array}{l}\text { General people; } 30.61 \pm \\
8.68 \text { years }\end{array}$ & $\begin{array}{l}11 \text { were COVID-19 infected, } \\
96 \text { were suspected of having } \\
\text { the COVID-19 infection }\end{array}$ & $\begin{array}{l}\text { Brazilian Fear of COVID-19 } \\
\text { Scale }\end{array}$ & $\begin{array}{l}\text { Fear of COVID-19 infection scores } \\
\text { were lower in males with } \\
\text { occupational risk of contamination, } \\
\text { whereas females and younger } \\
\text { individuals were at greater risk of } \\
\text { fear of COVID-19 }\end{array}$ \\
\hline Bakioğlu et al. (33) & $\begin{array}{l}\text { March to April } \\
2020\end{array}$ & $\begin{array}{l}\text { Cross- } \\
\text { sectional }\end{array}$ & 960 & Turkey & $\begin{array}{l}\text { General people; } 29.74 \pm \\
9.64 \text { years }\end{array}$ & $\begin{array}{l}\text { Details of whether COVID-19 } \\
\text { infected or under quarantine } \\
\text { is not specified }\end{array}$ & $\begin{array}{l}\text { Turkish Fear of COVID-19 } \\
\text { Scale }\end{array}$ & $\begin{array}{l}\text { Fear of COVID-19 infection scores } \\
\text { were higher in participants being } \\
\text { women and having chronic } \\
\text { illnesses; fear of COVID-19 was } \\
\text { correlated with intolerance of } \\
\text { uncertainty, depression, anxiety, } \\
\text { and stress }\end{array}$ \\
\hline Bäuerle et al. (34) & $\begin{array}{l}\text { March } 10 \text { to } \\
\text { May 5, } 2020\end{array}$ & $\begin{array}{l}\text { Cross- } \\
\text { sectional }\end{array}$ & 15,037 & Germany & General people; $\geq 18$ years & $\begin{array}{l}\text { Details of whether COVID-19 } \\
\text { infected or under quarantine } \\
\text { is not specified }\end{array}$ & $\begin{array}{l}\text { Self-developed single item } \\
\text { (response } 1 \text { to } 7 \text { ) }\end{array}$ & $\begin{array}{l}\text { Fear of COVID-19 infection scores } \\
\text { were lower in males, whereas } \\
\text { younger individuals were at greater } \\
\text { risk of having a fear of COVID-19 }\end{array}$ \\
\hline $\begin{array}{l}\text { Broche-Pérez et al. } \\
\text { (35) }\end{array}$ & $\begin{array}{l}\text { April } 4 \text { to May } \\
272020\end{array}$ & $\begin{array}{l}\text { Cross- } \\
\text { sectional }\end{array}$ & 772 & Cuba & $\begin{array}{l}\text { General people; } 36 \pm 14.61 \\
\text { years }\end{array}$ & $\begin{array}{l}\text { Details of whether COVID-19 } \\
\text { infected is not specified, but } \\
\text { participants were not under } \\
\text { quarantine }\end{array}$ & $\begin{array}{l}\text { Spanish (Cuban) Fear of } \\
\text { COVID-19 Scale }\end{array}$ & $\begin{array}{l}\text { Fear of COVID-19 infection scores } \\
\text { were more severe in female genders }\end{array}$ \\
\hline Doshi et al. (18) & $\begin{array}{l}\text { April } 25 \text { to } 26, \\
2020\end{array}$ & $\begin{array}{l}\text { Cross- } \\
\text { sectional }\end{array}$ & 1,499 & India & $\begin{array}{l}\text { General people; } 20-60+ \\
\text { years }\end{array}$ & $\begin{array}{l}\text { Details of whether COVID-19 } \\
\text { infected or under quarantine } \\
\text { is not specified }\end{array}$ & Fear of COVID-19 Scale & $\begin{array}{l}\text { Females, married status, lower } \\
\text { educational status, and being a } \\
\text { health care worker had higher levels } \\
\text { of fear of COVID-19 infection }\end{array}$ \\
\hline Fitzpatrick et al. (36) & $\begin{array}{l}\text { March } 23 \text { to } 30 \text {, } \\
2020\end{array}$ & $\begin{array}{l}\text { Cross- } \\
\text { sectional }\end{array}$ & 10,368 & US & General people; $\geq 18$ years & $\begin{array}{l}\text { Details of whether COVID-19 } \\
\text { infected or under quarantine } \\
\text { is not specified }\end{array}$ & $\begin{array}{l}\text { Self-developed single item } \\
\text { (response } 0 \text { to 10) }\end{array}$ & $\begin{array}{l}\text { Women, Hispanics, Asians, families } \\
\text { with children under } 18 \text {, and } \\
\text { foreign-born participants had higher } \\
\text { levels of subjective fear and worry } \\
\text { related to COVID-19 }\end{array}$ \\
\hline Haddad et al. (37) & $\begin{array}{l}\text { April } 3 \text { to } 18, \\
2020\end{array}$ & $\begin{array}{l}\text { Cross- } \\
\text { sectional }\end{array}$ & 407 & Lebanon & $\begin{array}{l}\text { General people; } 30.59 \pm \\
10.10 \text { years }\end{array}$ & $\begin{array}{l}\text { Details of whether covid-19 } \\
\text { infected is not specified, but } \\
\text { participants were either } \\
\text { quarantined or confined }\end{array}$ & $\begin{array}{l}\text { Self-developed single item } \\
\text { (response } 1 \text { to } 5 \text { ) }\end{array}$ & $\begin{array}{l}\text { Fear and anxiety were more and } \\
\text { more than half of the participants } \\
\text { were abiding by home } \\
\text { quarantine/confinement. }\end{array}$ \\
\hline Islam et al. (38) & $\begin{array}{l}\text { May } 5 \text { to } 15 \\
2020\end{array}$ & $\begin{array}{l}\text { Cross- } \\
\text { sectional }\end{array}$ & 340 & Bangladesh & $\begin{array}{l}\text { General people; } 26.23 \pm \\
6.39 \text { years }\end{array}$ & $\begin{array}{l}\text { Details of whether covid- } 19 \\
\text { infected or under quarantine } \\
\text { are not specified. }\end{array}$ & $\begin{array}{l}\text { Self-developed single item } \\
\text { (response } 1 \text { to } 6 \text { ) }\end{array}$ & $\begin{array}{l}\text { Fear of COVID-19 infection (i.e., self } \\
\text { and/or family member(s), and/or } \\
\text { relatives), hampering scheduled } \\
\text { study plan and future career, and } \\
\text { financial difficulties leading to } \\
\text { human stress. }\end{array}$ \\
\hline
\end{tabular}


TABLE 2 | Continued

\begin{tabular}{|c|c|c|c|c|c|c|c|c|}
\hline References & $\begin{array}{l}\text { Data } \\
\text { collection } \\
\text { time }\end{array}$ & $\begin{array}{l}\text { Study } \\
\text { design }\end{array}$ & $\begin{array}{l}\text { Sample } \\
\text { size }\end{array}$ & Country & $\begin{array}{l}\text { Specific group and mean } \\
\text { age }\end{array}$ & $\begin{array}{l}\text { Being COVID-19 infected } \\
\text { or suspected }\end{array}$ & Assessment tool & Outcome(s) \\
\hline Jaspal et al. (39) & Not reported & $\begin{array}{l}\text { Cross- } \\
\text { sectional }\end{array}$ & 411 & UK & $\begin{array}{l}\text { General people; } 48.85 \pm \\
15.38 \text { years }\end{array}$ & $\begin{array}{l}\text { Details of whether COVID-19 } \\
\text { infected is not specified, but } \\
\text { participants } 10 \% \text { were under } \\
\text { quarantine }\end{array}$ & Fear of COVID-19 Scale & $\begin{array}{l}\text { Muslims demonstrated higher levels } \\
\text { of fear than Christians }\end{array}$ \\
\hline Li et al. (40) & $\begin{array}{l}\text { December } \\
2019 \text { to April } \\
2020\end{array}$ & Longitudinal & 555 & China & $\begin{array}{l}\text { College students; } 19.6 \pm \\
3.4 \text { years }\end{array}$ & $\begin{array}{l}\text { Details of whether COVID-19 } \\
\text { infected is not specified, but } \\
\text { participants were confined } \\
\text { due to lockdown }\end{array}$ & $\begin{array}{l}\text { Self-developed single item } \\
\text { (response } 0 \text { to 10) }\end{array}$ & $\begin{array}{l}\text { Gender, negative mood, } \\
\text { depression, anxiety, etc. were } \\
\text { correlated with fear of COVID-19 } \\
\text { infection }\end{array}$ \\
\hline Mertens et al. (3) & Not reported & $\begin{array}{l}\text { Cross- } \\
\text { sectional }\end{array}$ & 439 & Global & $\begin{array}{l}\text { General people; } 26.0 \pm \\
11.7 \text { years }\end{array}$ & $\begin{array}{l}\text { Participants were not infected } \\
\text { with covid- } 19 \text {, but details } \\
\text { about being quarantined are } \\
\text { not specified }\end{array}$ & $\begin{array}{l}\text { Fear of the Coronavirus } \\
\text { Questionnaire }\end{array}$ & $\begin{array}{l}\text { Male gender, health anxiety, the risk } \\
\text { for loved ones, and looking up } \\
\text { additional information (i.e., through } \\
\text { regular media and social media) } \\
\text { were independent predictors for } \\
\text { fear of COVID-19 }\end{array}$ \\
\hline $\begin{array}{l}\text { Nicomedes and } \\
\text { Avila (19) }\end{array}$ & Not reported & $\begin{array}{l}\text { Mixed } \\
\text { method } \\
\text { cross- } \\
\text { sectional }\end{array}$ & 538 & Philippines & $\begin{array}{l}\text { General people; } 23.82 \\
\text { (range 13-67) years }\end{array}$ & $\begin{array}{l}\text { Participants were exposed to } \\
\text { COVID-19 infection, but } \\
\text { details related to quarantine } \\
\text { are not specified }\end{array}$ & $\begin{array}{l}\text { Self-developed qualitative } \\
\text { item }\end{array}$ & $\begin{array}{l}\text { Fear of COVID-19 infection was one } \\
\text { of the themes identified in this } \\
\text { qualitative study }\end{array}$ \\
\hline $\begin{array}{l}\text { Saurabh and Ranjan } \\
\text { (41) }\end{array}$ & Not reported & $\begin{array}{l}\text { Comparative } \\
\text { cross- } \\
\text { sectional (with } \\
131 \text { non- } \\
\text { quarantined) }\end{array}$ & 121 & India & $\begin{array}{l}\text { Children and Adolescents; } \\
\text { 9-18 years }\end{array}$ & $\begin{array}{l}\text { Participants were in primary } \\
\text { contact with COVID-19 } \\
\text { infected person and were } \\
\text { under quarantine just before } \\
\text { the study }\end{array}$ & Self-developed items & $\begin{array}{l}\text { Quarantined children and } \\
\text { adolescents experienced greater } \\
\text { psychological distresses (e.g., } \\
\text { worry, helplessness, fear related to } \\
\text { COVID-19) than non-quarantined }\end{array}$ \\
\hline Šljivo et al. (42) & $\begin{array}{l}\text { April } 7 \text { to } 12 \\
2020\end{array}$ & $\begin{array}{l}\text { Cross- } \\
\text { sectional }\end{array}$ & 1,201 & $\begin{array}{l}\text { Bosnia and } \\
\text { Herzegovina }\end{array}$ & $\begin{array}{l}\text { General people; } 30.57 \pm \\
11.26 \text { years }\end{array}$ & $\begin{array}{l}\text { Participants were not } \\
\text { covid- } 19 \text { infected, and details } \\
\text { related to quarantine are not } \\
\text { specified }\end{array}$ & Fear of COVID-19 Scale & $\begin{array}{l}\text { Being older, female, living in an } \\
\text { urban area, having moderate to } \\
\text { severe depressive symptoms were } \\
\text { significant independent predictors } \\
\text { for developing a fear of COVID-19 }\end{array}$ \\
\hline
\end{tabular}


professions such as healthcare professionals. In one study, it was associated with higher levels of COVID-19 fear (18), although men working in higher-risk occupations were found to have low levels of COVID-19 fear as per Andrade et al.'s study (32). Again, participants being in quarantine settings or with a suspicion of being infected with the virus showed elevated levels of COVID19 fear $(32,41)$. In addition, being Muslim compared to Christian (39), having maladaptive eating behaviors (37), even the COVID19 information sources $(3,39)$ were identified as increasing the risk of higher fear of COVID-19.

\section{Distribution of Fear of COVID-19 Across Cohorts}

\section{Fear of COVID-19 Among Children and Adolescents}

Only one study was specifically conducted among children and adolescents from 9 to 18 years of age who were in quarantine, which was a comparative study in nature (with non-quarantined ones) (41). The COVID-19 fear was assessed using a pre-formed questionnaire, whereas quarantined children and adolescents were found to experience greater psychological distress (e.g., worry, helplessness, fear related to COVID-19) than nonquarantined ones.

\section{Fear of COVID-19 Among Students}

The only longitudinal study was conducted to determine the mental health status of the college students in considering "before" and "during" confinement periods, where the fear of COVID-19 severity was reported higher after they were confined (40). In the students being confined, during the follow-up assessment, gender, negative mood, depression, anxiety, etc., were found to be correlating factors of COVID-19 fear (40).

\section{Fear of COVID-19 Among Adults}

Several studies were conducted among adults $(3,18,19,32-$ $38,42)$. Fitzpatrick et al. (36), in an online survey on people above 18 years of age, found that the fear of COVID-19 varied from region to region, and women especially were more vulnerable to COVID-19 fear. Similarly, females were reported to be at an increased risk of COVID-19 fear by another study (18), whereas being divorced and having a low educational background were other factors associated with fear of COVID-19.

\section{Fear of COVID-19 Among Older Adults and Elderly}

No studies were specifically conducted focusing on older adult cohort, although studies among general people found heterogeneous findings regarding elder age-related distribution of COVID-19 fear. That is, Doshi et al. (18) observed the participants being elderly (more than 60 years) were at lower risk of fear of COVID-19 compared to the groups of younger age. Whereas, 65.0 and $65.3 \%$ of the participants with $65-74$ years and more than 75 years old, respectively, had reported at risk of elevated COVID-19-related fear, which was $55.2 \%$ for the age group of 18-24 years (34).

\section{Fear of COVID-19 Among General Population}

Of the included studies, 12- were conducted among the general population (3, 18, 19, 32-39, 42). Hence, the population categories in terms of the extent of fear among children, adolescents, adults, and the elderly cannot be differentiated. The subgroup of the general population is reported as it included study participants, including children, adolescents, adults, and the geriatric population. Analysis of the specific cohorts from this sub-group may not convey any meaning as such, but the findings for the sub-group of the general population may help in making some sense of fear-related factors in various age groups. All the studies have identified many factors contributing to higher levels of fear of COVID-19. Specifically, a higher level of COVID-19 fear was observed in female participants $(32,33,35)$, but one of the studies also identified that the males were at a higher risk of fear of COVID-19 infection (3). Similarly, the contributing role of age in the participants' COVID-19 fear levels was reported in many studies $(18,32,34,42)$. Whereas, the only longitudinal study (40) observed an increment trend of COVID-19 fear compared while the participants were confined as similarly observed in another study (37). In addition, the only qualitative study found the panic responses of the general population related to the COVID-19 pandemic, in which fear was one of the themes identified (19). Two studies identified that fear of COVID-19 infection was higher in people exposed more to media for information on COVID-19 compared to others $(3,39)$.

\section{DISCUSSION}

To the best of the author's knowledge, no prior review was conducted summing up the COVID-19 fear, like other mental health problems related to the pandemic. Therefore, the present scoping review being very first in this context, is anticipated to help gauge the extent of fear of COVID-19 in various populations such as children, adolescents, adults, and older adults. Thus, the findings reported herein may help to predict the possible reasons for fear of COVID-19 and also facilitate further research on strategies to alleviate such a situation.

Based on the present findings, it is evident that female genders are at higher risk of fear of COVID-19 infection $(18,32,33,35$, 36, 42). The reason for gender-based heterogeneity in contributing fear of COVID-19 can be explained by the prior studies, whereas males were reported as having irresponsible attitudes toward the COVID-19 pandemic, which dramatically decreases their consciousness about the potential infection of the virus (43, 44). In addition, studies have reported that women experience more fear and anxiety $(45,46)$; however, they are more resilient and deal well in difficult times (33). Besides this, some aging people are at lower risk of COVID-19 fear $(32,34)$, which can be attributed to these adults' resilience and coping strategies (47, 48). Furthermore, older adults' successful involvement in community and family-related activities, favorable physical and mental health would have contributed to their resilience resulting in less fear in the older population in comparison with the younger populations - which is suggested to focus on policy actions.

One of the studies by Jaspal et al. (39) has identified the association between religion and levels of fear of COVID19 and found that Muslims demonstrated higher levels of fear than Christians. This was associated with their sources of information and other stressors. COVID-19 fear was also 
associated with eating disorders in a sample in Lebanon (37). Some studies have also tried to explore the pathways through which several factors affect mental health. Fear of COVID-19 was found to be associated with job insecurity and depression, insomnia etc. $(49,50)$, whereas Mahmud et al. (51) found a mediating role of fear of COVID-19 infection between depression related to COVID-19 and career anxiety. In addition, there seems to be an association between the information people look up through various sources and fear $(3,39)$. Intense fear can influence decision-making capacities, emotional regulation capacities, and relationship issues in people; which is suspected to be considered in policy practice (52).

The extent of COVID-19 fear may influence an individual's participation in daily life activities and follow up with the guidelines introduced by the government. Most of the included studies examined anxiety and depression and other mental health problems by established assessment tools, although it is fear of COVID-19 which was assessed by the developed tool, Fear of COVID-19 Scale, in a total of 6-studies. Fear of COVID-19 Scale has good psychometric properties and is being widely used to measure fear related to the COVID-19 pandemic (53). Therefore, it is recommended to be considered in future research as fear is a key source of anxiety and distress-related mental health problems (49). Besides, all of the studies were carried out by online surveys, which increases the risk of potential for selection bias. These studies might not represent the true population due to the over-representation of certain groups like women and younger adults. In addition, all studies except one have a cross-sectional design; therefore, causal relationships reported by the individual studies cannot be inferred. Although studies included in this review were from various parts of the world, generalizations should be made more cautiously.

Another factor that needs to be considered here is the occupation of the participants included. Though the current review did not include studies done specifically on health care workers, it is unsure whether the included studies herein were conducted on the general population, including healthcare workers. Therefore, it is suggested to provide more information on study participants to make a better comparison across studies because healthcare professionals are found to have higher fear of COVID-19 due to higher exposure in healthcare settings, leading to suicide $(54,55)$. Another drawback is that none of the included studies reported any information related to the participants' mental health disorders, which may attribute fear of COVID-19 to a great extent (56).

Most of the studies included in the current review assessed the fear during the initial phases of the pandemic, that is, from March to May 2020, when the whole world was facing the first wave of the COVID-19 pandemic. Associations existed between seeking information on COVID-19 related information on social media and its fear (57), which could have been more during the initial stages of the pandemic. The studies included have assessed fear using self-developed items that are not standardized, and hence the reliability of the results obtained can be questionable. Nevertheless, a few studies have used the fear of COVID-19 scale to assess the extensively used fear and evaluate fear explicitly related to COVID-19. Furthermore, most of the studies included are cross-sectional in nature the temporal relationship between the COVID19 infection and fear cannot be inferred. In addition, the quality of the included study (e.g., time length of the survey, the validity of the measurement tool, and how statistical significance of the association factors) could be added to construct the concrete of the study finding interpretation, which may limit the findings. However, being one of the first approaches summarizing the fear of COVID-19, the limitations of this scoping review are supposed to be addressed in further reviews.

\section{CONCLUDING REMARKS}

The COVID-19 pandemic has helped draw attention to the issues that affect physical and mental health. Studies that further our understanding of these issues are just gathering up, where the present review adds baseline information to this context. However, it is important to consider the long-term consequences of the pandemic as this pandemic unfolds at different speeds in various parts of the world. Low-and middleincome countries that are struggling with resources to fight the disease and dealing with a huge burden of poverty and hunger have gotten more than they can handle. Fear of COVID19 has induced unwanted reactions in people from running away from their livelihoods to commit suicide to an increase in domestic violence. It is important to understand what people are afraid of during these pandemics, the associated factors, and how this can be alleviated or at least be managed. Longterm effects of COVID-19 fear can be dangerous and grow into adverse effects later in life. This review illustrated that people are afraid of getting infected either for themselves or their loved ones. Mostly women, younger adults, and information gathered through media are associated with the fear of COVID19. It is important to keep in mind that several programs try to induce fear to improve compliance for protective behavior. However, studies have demonstrated that this strategy does not work (58). Therefore, these messages should be informative rather than being fear-inducing. This review underlines the fact that further studies are required investigating fear of COVID, as the world is moving into the second year of the COVID-19 pandemic with more aggressive infections sweeping many areas.

Being one of the first reviews in this context, the findings are anticipated to be helpful to predict the possible solutions for reducing fear of COVID-19 and facilitate further studies on strategies of how to alleviate such a stressful situation. The vulnerable population and associated factors of COVID fear identified through this review may help policymakers develop appropriate strategies to handle the current crisis of long-term effects of the pandemic on people's mental health.

\section{AUTHOR CONTRIBUTIONS}

SQ and SG have contributed to the initial pilot search, planning the methodology, and writing. RR and GV have contributed to 
planning the methodology, data gathering, and reviewing the draft. MM has contributed to planning the methodology and writing. SQ and MM addressed the reviewers' comments and revised the manuscript critically. All authors approved the final version of the manuscript.

\section{REFERENCES}

1. Mamun MA. Suicide and suicidal behaviors in the context of COVID-19 pandemic in Bangladesh: a systematic review. Psychol Res Behav Manag. (2021) 14:695-704. doi: 10.2147/PRBM.S315760

2. al Mamun F, Hosen I, Misti JM, Kaggwa MM, Mamun MA. Mental disorders of bangladeshi students during the COVID-19 pandemic: a systematic review. Psychol Res Behav Manag. (2021) 14:645-54. doi: 10.2147/PRBM.S315961

3. Mertens G, Gerritsen L, Duijndam S, Salemink E, Engelhard IM. Fear of the coronavirus (COVID-19): predictors in an online study conducted in March 2020. J Anxiety Disord. (2020) 74:102258. doi: 10.1016/j.janxdis.2020.102258

4. World Health Organization. Mental Health and COVID-19. (2020). Available online at: https:/www.euro.who.int/en/health-topics/noncommunicablediseases/mental-health/data-and-resources/mental-health-and-covid-19 (accessed October 10, 2020).

5. Centers for Disease Control and Prevention. Coping with Stress. (2021). Available online at: https://www.cdc.gov/coronavirus/2019-ncov/daily-lifecoping/managing-stress-anxiety.html (accessed August 5, 2021).

6. Mamun MA, Sakib N, Gozal D, Bhuiyan AKMI, Hossain S, Bodrud-Doza $\mathrm{M}$, et al. The COVID-19 pandemic and serious psychological consequences in Bangladesh: a population-based nationwide study. J Affect Disord. (2021) 279:462-72. doi: 10.1016/j.jad.2020.10.036

7. Kahil K, Cheaito MA, El Hayek R, Nofal M, El Halabi S, Kudva $\mathrm{KG}$, et al. Suicide during COVID-19 and other major international respiratory outbreaks: a systematic review. Asian J Psychiatr. (2020) 56:e102509. doi: 10.1016/j.ajp.2020.102509

8. Cheung YT, Chau PH, Yip PSF. A revisit on older adults suicides and severe acute respiratory syndrome (SARS) epidemic in Hong Kong. Int J Geriatr Psychiatry. (2008) 23:1231-8. doi: 10.1002/gps.2056

9. Yip PSF, Cheung YT, Chau PH, Law YW. The impact of epidemic outbreak: the case of severe acute respiratory syndrome (SARS) and suicide among older adults in Hong Kong. Crisis. (2010) 31:86-92. doi: 10.1027/0227-5910/a000015

10. Dsouza DD, Quadros S, Hyderabadwala ZJ, Mamun MA. Aggregated COVID-19 suicide incidences in India: Fear of COVID-19 infection is the prominent causative factor. Psychiatry Res. (2020) 290:e113145. doi: 10.1016/j.psychres.2020.113145

11. Griffiths MD, Mamun MA. COVID-19 suicidal behavior among couples and suicide pacts: case study evidence from press reports. Psychiatry Res. (2020) 289:e113105. doi: 10.1016/j.psychres.2020.113105

12. Taylor S, Landry CA, Paluszek MM, Fergus TA, McKay D, Asmundson GJG. COVID stress syndrome: concept, structure, and correlates. Depress Anxiety. (2020) 37:706-714. doi: 10.1002/da.23071

13. Schimmenti A, Billieux J, Starcevic V. The four horsemen of fear: an integrated model of understanding fear experiences during the COVID-19 pandemic. Clin Neuropsychiatry. (2020) 17:41-5. doi: 10.36131/CN20200202

14. Ahorsu DK, Lin C-Y, Imani V, Saffari M, Griffiths MD, Pakpour AH. The fear of COVID-19 scale: development and initial validation. Int J Ment Health Addict. (2020). doi: 10.1007/s11469-020-00270-8. [Epub ahead of print].

15. American Psychological Association. APA dictionary of psychology: fear. Am Psychol Assoc (2020). Available online at: https://dictionary.apa.org/fear (accessed October 10, 2020).

16. Liu Q, Luo D, Haase JE, Guo Q, Wang XQ, Liu S, et al. The experiences of health-care providers during the COVID19 crisis in China: a qualitative study. Lancet Glob Heal. (2020) 8:e790-8. doi: 10.1016/S2214-109X(20)30204-7

17. Law M. Participation in the occupations of everyday life. Am J Occup Ther Off Publ Am Occup Ther Assoc. (2002) 56:640-9. doi: 10.5014/ajot.56.6.640

\section{ACKNOWLEDGMENTS}

MM would like to acknowledge their affiliation, the CHINTA Research Bangladesh, formerly known as the Undergraduate Research Organization.

18. Doshi D, Karunakar P, Sukhabogi JR, Prasanna JS, Mahajan S V. Assessing coronavirus fear in Indian population using the fear of COVID-19 scale. Int J Ment Health Addict. (2020). doi: 10.1007/s11469-020-00 332-x. [Epub ahead of print].

19. Nicomedes CJC, Avila RMA. An analysis on the panic during COVID19 pandemic through an online form. J Affect Disord. (2020) 276:1422. doi: $10.1016 /$ j.jad.2020.06.046

20. Whiteford G. Occupational deprivation: global challenge in the new millennium. Br J Occup Ther. (2000) 63:2004. doi: 10.1177/030802260006300503

21. Kuy S, Tsai R, Bhatt J, Chu QD, Gandhi P, Gupta R, et al. Focusing on vulnerable populations during COVID-19. Acad Med. (2020). 95:e2-e3 doi: 10.1097/ACM.0000000000003571

22. Lauvrak V, Juvet L. Social and economic vulnerable groups during the COVID-19 pandemic. Nor Inst Public Heal. (2020). Available online at: https://www.fhi.no/globalassets/dokumenterfiler/rapporter/2020/social-andeconomic-vulnerable-groups-during-the-covid-19-pandemic-report-2020v3.pdf (accessed October 10, 2020).

23. Khan KS, Mamun MA, Griffiths MD, Ullah I. The mental health impact of the COVID-19 pandemic across different cohorts. Int J Ment Health Addict. (2020). doi: 10.1007/s11469-020-00367-0. [Epub ahead of print].

24. Schaller M, Park JH. The behavioral immune system (and why it matters). Curr Dir Psychol Sci. (2011) 20:99-103. doi: 10.1177/0963721411402596

25. Iwasa K, Yamada Y, Tanaka T. Editorial: behavioral immune system: its psychological bases and functions. Front Psychol. (2021) 12:659975. doi: 10.3389/fpsyg.2021.659975

26. Allan NP, Norr AM, Capron DW, Raines AM, Zvolensky MJ, Schmidt NB. Specific associations between anxiety sensitivity dimensions and fear and distress dimensions of emotional distress disorders. J Psychopathol Behav Assess. (2015) 37:67-78. doi: 10.1007/s10862-014-9437-y

27. Gallagher M, Muldoon OT, Pettigrew J. An integrative review of social and occupational factors influencing health and wellbeing. Front Psychol. (2015) 6:1281. doi: 10.3389/fpsyg.2015.01281

28. Munn Z, Peters MDJ, Stern C, Tufanaru C, McArthur A, Aromataris E. Systematic review or scoping review? Guidance for authors when choosing between a systematic or scoping review approach. BMC Med Res Methodol. (2018) 18:1-7. doi: 10.1186/s12874-018-0611-x

29. Tricco AC, Lillie E, Zarin W, O’Brien KK, Colquhoun H, Levac D, et al. PRISMA extension for scoping reviews (PRISMA-ScR): checklist and explanation. Ann Intern Med. (2018) 169:467-73. doi: 10.7326/M18-0850

30. Arksey H, O'Malley L. Scoping studies: towards a methodological framework. Int $J$ Soc Res Methodol Theory Pract. (2005) 8:19-32. doi: 10.1080/1364557032000119616

31. Shamseer L, Moher D, Clarke M, Ghersi D, Liberati A, Petticrew M, et al. Preferred reporting items for systematic review and meta-analysis protocols (PRISMA-P) 2015: elaboration and explanation. BMJ. (2015) 350:g7647. doi: 10.1136/bmj.g7647

32. Andrade EF, Pereira LJ, de Oliveira APL, Orlando DR, Alves DAG, Guilarducci J de S, et al. Perceived fear of COVID-19 infection according to sex, age and occupational risk using the Brazilian version of the fear of COVID-19 scale. Death Stud. (2020). doi: 10.1080/07481187.2020.1809786. [Epub ahead of print].

33. Bakioǧlu F, Korkmaz O, Ercan H. Fear of COVID-19 and positivity: mediating role of intolerance of uncertainty, depression, anxiety, and stress. Int J Ment Health Addict. (2020). doi: 10.1007/s11469-020-00331-y. [Epub ahead of print].

34. Bäuerle A, Teufel M, Musche V, Weismüller B, Kohler H, Hetkamp M, et al. Increased generalized anxiety, depression and distress during the COVID-19 
pandemic: a cross-sectional study in Germany. J Public Health. (2020) 42:6728. doi: 10.1093/pubmed/fdaa106

35. Broche-Pérez Y, Fernández-Fleites Z, Jiménez-Puig E, Fernández-Castillo E, Rodríguez-Martin BC. Gender and fear of COVID-19 in a Cuban population sample. Int $J$ Ment Health Addict. uncertainty, depression, anxiety (2020). doi: 10.1007/s11469-020-00377-y. [Epub ahead of print].

36. Fitzpatrick KM, Harris C, Drawve G. Living in the midst of fear: depressive symptomatology among US adults during the COVID19 pandemic. Depress Anxiety. (2020) 37:957-64. doi: 10.1002/da. 23080

37. Haddad C, Zakhour M, Bou Kheir M, Haddad R, Al Hachach M, Sacre $\mathrm{H}$, et al. Association between eating behavior and quarantine/confinement stressors during the coronavirus disease 2019 outbreak. J Eat Disord. (2020) 8:40. doi: 10.1186/s40337-020-00317-0

38. Islam SMDU, Bodrud-Doza M, Khan RM, Haque MA, Mamun MA. Exploring COVID-19 stress and its factors in Bangladesh: a perception-based study. Heliyon. (2020) 6:e04399. doi: 10.1016/j.heliyon.2020.e04399

39. Jaspal R, Lopes B, Lopes P. Fear, social isolation and compulsive buying in response to COVID-19 in a religiously diverse UK sample. Ment Health Relig Cult. (2020) 23:427-42. doi: 10.1080/13674676.2020.1784119

40. Li HY, Cao H, Leung DYP, Mak YW. The psychological impacts of a COVID-19 outbreak on college students in China: a longitudinal study. Int J Environ Res Public Health. (2020) 17:3933. doi: 10.3390/ijerph171 13933

41. Saurabh K, Ranjan S. Compliance and psychological impact of quarantine in children and adolescents due to Covid-19 pandemic. Indian J Pediatr. (2020) 87:532-6. doi: 10.1007/s12098-020-03347-3

42. Šljivo A, Kačamaković M, Quraishi I, DŽubur Kulenović A. Fear and depression among residents of Bosnia and Herzegovina during COVID-19 outbreak - internet survey. Psychiatr Danub. (2020) 32:26672. doi: $10.24869 /$ psyd.2020.266

43. Hosen I, Pakpour AH, Sakib N, Hussain N, al Mamun F, Mamun MA. Knowledge and preventive behaviors regarding COVID-19 in Bangladesh: a nationwide distribution. PLoS ONE. (2021) 16:e0251151. doi: 10.1371/journal.pone.02 51151

44. Islam SMDU, Safiq MB, Bodrud-Doza M, Mamun MA. Perception and attitudes towards PPE-related waste disposal amid COVID19 in Bangladesh: An exploratory study. Front Public Heal. (2020) 8:699. doi: $10.3389 /$ fpubh.2020.592345

45. Lim GY, Tam WW, Lu Y, Ho CS, Zhang MW, Ho RC. Prevalence of depression in the community from 30 countries between 1994 and 2014. Sci Rep. (2018) 8:2861. doi: 10.1038/s41598-018-2 $1243-\mathrm{x}$

46. Wang C, Pan R, Wan X, Tan Y, Xu L, Ho CS, et al. Immediate psychological responses and associated factors during the initial stage of the 2019 coronavirus disease (COVID-19) epidemic among the general population in China. Int J Environ Res Public Health. (2020) 17:1729. doi: 10.3390/ijerph17051729

47. MacLeod S, Musich S, Hawkins K, Alsgaard K, Wicker ER. The impact of resilience among older adults. Geriatr Nurs. (2016) 37:26672. doi: 10.1016/j.gerinurse.2016.02.014

48. Ribeiro M dos S, Borges M da S, Araújo TCCF de, Souza MC dos S. Coping strategies used by the elderly regarding aging and death: an integrative review. Rev Bras Geriatr e Gerontol. (2017) 20:86977. doi: 10.1590/1981-22562017020.170083
49. Gasparro R, Scandurra C, Maldonato NM, Dolce P, Bochicchio V, Valletta $\mathrm{A}$, et al. Perceived job insecurity and depressive symptoms among Italian dentists: the moderating role of fear of COVID-19. Int J Environ Res Public Health. (2020) 17:5338. doi: 10.3390/ijerph17155338

50. al Mamun F, Gozal D, Hosen I, Misti JM, Mamun MA. Predictive factors of insomnia during the COVID-19 pandemic in Bangladesh: a GIS-based nationwide distribution. Sleep Med. (2021). doi: 10.1016/j.sleep.2021.04.025. [Epub ahead of print].

51. Mahmud MS, Talukder MU, Rahman SM. Does "Fear of COVID-19" trigger future career anxiety? An empirical investigation considering depression from COVID-19 as a mediator. Int $J$ Soc Psychiatry. (2020). doi: 10.1177/0020764020935488. [Epub ahead of print].

52. Harbin A. Inducing fear. Ethical Theory Moral Pract. (2020) 23:50113. doi: $10.1007 / \mathrm{s} 10677-020-10103-1$

53. Lin C-Y, Hou W-L, Mamun MA, Aparecido da Silva J, Broche-Pérez Y, Ullah I, et al. Fear of COVID-19 scale (FCV-19S) across countries: measurement invariance issues. Nurs Open. (2021). 8:1892-1908 doi: 10.1002/nop2.855

54. Mamun MA, Bodrud-Doza M, Griffiths MD. Hospital suicide due to nontreatment by healthcare staff fearing COVID-19 infection in Bangladesh? Asian J Psychiatr. (2020) 54:e102295. doi: 10.1016/j.ajp.2020.102295

55. Jahan I, Ullah I, Griffiths MD, Mamun MA. COVID-19 suicide and its causative factors among the healthcare professionals: case study evidence from press reports. Perspect Psychiatr Care. (2021). doi: 10.1111/ppc.12739. [Epub ahead of print].

56. Ahorsu DK, Imani V, Lin C-Y, Timpka T, Broström A, Updegraff JA, et al. Associations between fear of COVID-19, mental health, and preventive behaviours across pregnant women and husbands: an actor-partner interdependence modelling. Int $J$ Ment Health Addict. (2020). doi: 10.1007/s11469-020-00340-x. [Epub ahead of print].

57. Bendau A, Petzold MB, Pyrkosch L, et al. Associations between COVID-19 related media consumption and symptoms of anxiety, depression and COVID-19 related fear in the general population in Germany. Eur Arch Psychiatry Clin Neurosci. (2021) 271:283-91. doi: 10.1007/s00406-020-01171-6

58. Tannenbaum MB, Hepler J, Zimmerman RS, Saul L, Jacobs S, Wilson K, et al. Appealing to fear: a meta-analysis of fear appeal effectiveness and theories. Psychol Bull. (2015) 141:1178-204. doi: 10.1037/a0039729

Conflict of Interest: The authors declare that the research was conducted in the absence of any commercial or financial relationships that could be construed as a potential conflict of interest.

Publisher's Note: All claims expressed in this article are solely those of the authors and do not necessarily represent those of their affiliated organizations, or those of the publisher, the editors and the reviewers. Any product that may be evaluated in this article, or claim that may be made by its manufacturer, is not guaranteed or endorsed by the publisher.

Copyright $\odot 2021$ Quadros, Garg, Ranjan, Vijayasarathi and Mamun. This is an open-access article distributed under the terms of the Creative Commons Attribution License (CC BY). The use, distribution or reproduction in other forums is permitted, provided the original author(s) and the copyright owner(s) are credited and that the original publication in this journal is cited, in accordance with accepted academic practice. No use, distribution or reproduction is permitted which does not comply with these terms. 